\title{
Basal Decidual Necrosis
}

National Cancer Institute

\section{Source}

National Cancer Institute. Basal Decidual Necrosis. NCI Thesaurus. Code C118159.

Acellular areas of the basal plate. 